\title{
Preface and
}

Acknowledgments 
We would like to thank all those who have supported us with advice, assistance, and funding, above all the Swiss National Science Foundation (SNSF) and the Zurich University of the Arts. Our heartfelt thanks to Scott deLahunta for providing the initial inspiration and bringing people together, to Florian Dombois for contributing so many ideas at the outset of the project, and to Anton Rey for offering advice when the project encountered crises. We would also like to thank everyone who tested our prototype and gave us feedback, especially the participants at the Research Academy 2018 in Zurich.

It is our hope that with the Research Video project we can contribute to ensuring that artistic research can maintain its proximity to artistic and creative experience. This has been important to us right from the beginning. We have not endeavored to develop an overly theoretical method, but instead have aimed to create a direct approach to generating knowledge that also benefits artists and designers.

The more we approach things with an open mind, the betterthat was our guiding principle. Artistic and design research should not be allowed to stray too far from practice; otherwise, it may lose sight of what can make it so valuable.

\section{Zürich 2021}

The team of the Research Video project

Gunter Lösel

Martin Zimper

Marisa Godoy

Léa Klaue

Martin Grödl

Moritz ResI

Eric Andreae

Susanne Schumacher

Thomas Schank 